\title{
Differences in Leadership Behaviour between Expatriates and Local Managers as Perceived by Their Indonesian Subordinates
}

\section{Perbedaan Perilaku Kepemimpinan antara Ekspatriat dan Manajer Lokal Dilihat dari Pandangan Bawahan Indonesia}

\author{
Lily Deviastri \\ Faculty of Economics, Universitas YARSI \\ E-mail: lily.deviastri@yarsi.ac.id
}

KATA KUNCI perilaku kepemimpinan, ekspatriat, manajer local

ABSTRAK Penelitian ini dilakukan untuk mengetahui adanya perbedaan perilaku kepemimpinan antara ekspatriat dan manajer lokal dilihat dari sudut pandang bawahan mereka yang berkewarganegaraan Indonesia. Data diambil dari 13 perusahaan multinasional dan organisasi non pemerintah skala internasional di Jakarta. Hasil yang diperoleh mengindikasikan bahwa terdapat perbedaan yang signifikan antara dua kategori manajer yang mempengaruhi cara mereka menjelaskan peran kepada kelompok, melakukan persuasi, mentoleransi ketidakjelasan serta memandang bentuk kenyamanan dan status.

\section{INTRODUCTION}

The increasing activities of international business affecting multinational companies to expand their business, therefore managers around the world are involved to some degree in international activites which mandates them to develop the skills necessary for effective cross-cultural interactions and daily operations in foreign subsidiaries, since management should consider the nature of host culture and its relationship to management style (Jackson, 1995, p. 64).

Regarding to that situation, it is very important for global operation multinationals to learn and be compatible with the environment in order to keep up with the rotation of international business. Therefore, it is necessary for companies to hire qualified managers. Qualified managers can be measured by their academic ability, and also the way they lead their subordinates stimulating productivity, achieving the company's goals and objectives. Leadership is considered to be important for a manager since, according to Bass (1990) leadership is the focus of group processes that involves personality and its effect to exercise influence that lead to an act or behavior.

The need for qualified managers is vital. To meet the demand, companies may hire managers that originated from the country that the company is located or either non-citizens of country in which they are working known as expatriates (Desler, 2000, p. 621). Most companies employ expatriates because the lack of availability of management and technical skills in some countries, and also the objective of control of local operations (Brewster \& Suutari, 2001, p. 555). However, without any cultural preparation and inadequate cross cultural understanding, expatriates are likely to apply the same leadership behavior as they do in their home country. Previous 
research showed that inadequate crosscultural understanding and intercultural abilities resulted significant premature return rates, each failure gives rise to substantial direct and indirect costs, a notable share of expatriates managers who stay on are regarded as ineffective by their parent organizations, and inefective expatriate managers acquire direct and indicrect costs (Selmer, 1997, p.13). Beside direct and indirect costs, there also 'invisible' costs due to a manager's failure oevrseas: the loss of self-esteem and selfconfidence in the expatriate's managerial ability and the loss of prestige among one's peers (Mendenhall \& Oddou, 1985, p. 39).

Cultural itself refers to those learned behaviours characterizing the total way of life of members within any given society and culture results in a basis for living grounded in shared communication, standard, codes of conduct, and expectations.

Hence, it is critical for the expatriates working in foreign culture to have a working knowledge of the cultural variable that effects management decisions. And to avoid the blunder in international operations caused by the cultural differences, the skills of cultural sensitivity is greatly required.

Realizing that condition, this study tried to seek differences in leadership behavior between expatriates and local manager, therefore the research title is The Differences In Leadership Behavior Between Expatriates And Local Managers As Perceived By Their Indonesian Subordinates.

\section{RESEARCH METHODOLOGY}

This study uses a quantitative method with survey as the research instrument. Research by survey requires a standard format, for example, a questionnaire, which is used to define or describe variables, and to analyze the relationship between variables (Malhotra \& Grover, 1998). The unit analyses of the study are Indonesian subordinates derived from 13 multinational companies and nongovernmental organization in Jakarta, which had experience working with both expatriates and local managers. Expatriates in this study were those originated from the US and European countries working in the oil and gas industry or at the nongovernmental organizations in Jakarta. The questionnaire used in this survey is a modified version of the Leadership Behaviour Description Questionnaire (LBDQ) by Stogdill (1959). To the four original LBDQ instrument, 2-response dimension pertaining to "expatriate manager" and "local manager" will be added. These dimensions serve to measure the leadership behaviour of two categories of superiors as perceived by the respondents.

Background variables will be added to the original set of items. Each item has two 5-point Likert -type scale (1=very little; 5=great deal), refering to two kinds of managers (expatriates (EB) and local managers (LM).

The 4 instruments of LBDQ subscales represent a complex and varied pattern of leadership behaviour described as follows (Stogdill, 1963):

1. Tolerance of ncertainty depicts to what degree the manager is able to tolerate uncertainty and postponement without anxiety or getting upset.

2. Persuasiveness measures to what extent the manager uses persuasion and argument effectively.

3. Initiating Structure measures to what extent the manager clearly defines own role, and lets followers know what is expected.

4. Consideration depicts to what extent the manager regards the comfort, well being, status and contributions of followers. 


\section{RESULTS AND DISCUSSION}

The respondents comprised of Indonesian subordinates, that had experienced worked under expatriates and local managers' leadership. The researcher received 52 usable response from 80 questionnaires distributed. From the 52 questionaires, it was identified that $56.2 \%$ are male, while the rest are female. In terms of age, currently findings show that most respondents who filled the questionnaires $(43,8 \%)$ in age from $25-30$ years old. There are $49.3 \%$ held the staff position, $21,9 \%$ in middle management, and $28.8 \%$ in first level management. Mostly, the respondents had experienced worked under both categories of managers between 1 to 5 years. Each respondent represented a different company that has management, which led by expatriates and local managers, and operates internationally.

Data normality test is required to determine whether the statistics techniques used is parametric or non-parametric. In order to determine which technique is properly to be used in data analysis, a preceding test should be done to test normality of data distribution. If sample data is normally distributed, parametric statistic is suitable. Meanwhile, nonparametric statistic fit if sample data proven not normally distributed. Onesample Kolmogorov-Smirnov test was used to find out whether the data was normally distributed or not (Sugiyono, 1999, p.63).

Table 1. One-Sample Kolmogorov-Smirnov Test

\begin{tabular}{|c|c|c|c|c|c|}
\hline & \multirow{2}{*}{$\mathrm{N}$} & \multicolumn{2}{|c|}{ Normal Paramater } & \multirow{2}{*}{$\begin{array}{c}\text { Kolmogorov- } \\
\text { Smirnov Z }\end{array}$} & Asymp. \\
\hline & & Mean & Std. deviation & & (alleu) \\
\hline INIT & 52 & 3.4385 & .6098 & .753 & .622 \\
\hline CONSIDER & 52 & 3.5577 & 6191 & 1.098 & .179 \\
\hline TOLERANCE & 52 & 3.2466 & .4924 & 1.068 & .204 \\
\hline PERSUASI & 52 & 3.3769 & .5407 & .919 & .366 \\
\hline
\end{tabular}

From the table 1 above shown that mean score for Initiating Structure is 3.44, for consideration is 3.56 , tolerance of uncertainty is at 3.25 , and persuasiveness is as at 3.38 with scale 1 (strongly disagree) to 5 (strongly agree).

Based on the test conducted on 52 respondents using SPSS 11,0, the result displayed that all of the variable are normally distributed with significance level more then 0.05 ( $\mathrm{sig}>0.05$ ). Initiating structure is shown significance at level 0.622 , Consideration shows significance level at 0,179 , Tolerance of Uncertainty had significance at level 0.204, and Persuasiveness shown significance level of 0.366. Because of the Asymp. Sig $>\alpha$ (0.05), H0 is accepted or the data sample is normally distributed. Those four sub dimenstions had followed normal curve.

To compare leadership behaviour between exptriates and local managers, the research used independent sample t-test. One of the qualification to use this method is that the data is normally distributed and has the same variance. And to test the homogeny of variance used Levene test. The first condition had been completed. 
Table 2. Lavene Test For Equality of Variances

\begin{tabular}{ccc}
\hline & F & Sig. \\
\hline INIT & 0.096 & 0.758 \\
Consider & 0.249 & 0.62 \\
Tolerance & 0.028 & 0.868 \\
Persuasi & 0.089 & 0.766 \\
\hline
\end{tabular}

From the table 2 showed that significant level for each variable is: 0.758 for initiating structure, 0.620 for consideration, 0.868 for tolerance of uncertainty and 0.766 for persuasiveness. All the variables are $>0.05$, then the null hypotheses accepted, means that the data variance for these variables in this research are the same between expatriates and local managers. The second condition to conduct t-test had been accomplished.

After analyzing the data normality test, the researcher chosen to use t-test that aims to test the hypotheses and since the research data is in the form of sample, it was vital to use descriptive statistics.

The means and standard deviation of each nationality, which are Indonesia,
US, European and other Asian countries, amongst the four variables, were calculated by using statistical program SPSS 11.0.

Statistical inference was conducted using t-test that aims to test the hypotheses. In this case The main hypothesis that tested is:

- Ho: There is no difference in leadership behaviour between expatriates and local as perceived by their Indonesian subordinates

- H1: There is a difference in leadership behaviour between exptriates and local managers as perceived by their Indonesian subordinates.

Table 3. Independent Sample t Test in Leadership Behaviour between Expatriates and Local Managers

\begin{tabular}{lcccccc}
\hline $\begin{array}{c}\text { Dimension of } \\
\text { Leadership } \\
\text { Behaviour }\end{array}$ & Local Boss & Expatriate Boss & $\begin{array}{c}\text { Differences between } \\
\text { expatriate \& local } \\
\text { boss }\end{array}$ \\
\cline { 2 - 7 } & Mean & SD & Mean & SD & Mean & SD \\
\hline $\begin{array}{l}\text { Initiation of } \\
\text { Structure }\end{array}$ & 2.960 & 0.5667 & 3.632 & 0.5175 & -0.6724 & 0.000 \\
\hline Consideration & 3.107 & 0.4891 & 3.741 & 0.5752 & -0.6339 & 0.000 \\
\hline $\begin{array}{l}\text { Tolerance of } \\
\text { Uncertainty }\end{array}$ & 3.188 & 0.5027 & 3.270 & 0.4932 & -0.0821 & 0.591 \\
\hline Persuasiveness & 3.280 & 0.4346 & 3.416 & 0.579 & -0.1362 & 0.416 \\
\hline
\end{tabular}

\section{Hypothesis \# 1}

By applying t-test (Table 3), it was proved that Sig. 2-tailed $(0.000)<(0.01)$. As a result, the null hypothesis is rejected. Consequently, there is a significant difference in leadership behaviour for Initiating Structure between expatriates and local managers. The result is consistent to previous research conducted by Selmer (1997) with significant value of (0.016). 
However, the recent finding is still the same in the category that there is difference in terms of Initiating Structure between expatriates and local managers. So that, it can be concluded that this recent results have had a consistent result from the past research until now.

\section{Hypothesis \#2}

The current study shows the consistency result of 0.000 , which mean is lower than 0.01 . Therefore, the null hypothesis is rejected meaning that there is a difference in terms of Consideration.

\section{Hypothesis \#3}

Based on the test statistic, it can be summarized that there is no difference in leadership behaviour for Tolerance of Uncertainty between expatriates and local managers, because the significat value is 0.591 , which is above 0.1 . This result has discrepancy with the prior research conducted by Selmer (1997), which stated that there is a difference in terms of Tolerance of Uncertainty with $\mathrm{p}$ value $(0.015)<(0.05)$. The study by Littrel, 2002 , p. 40 p. also found that there is no difference between expatriates and local bosses for this dimension.

\section{Hypothesis \#4}

The result shows the $\mathrm{p}$ value of $(0.416)>$ $(0.1)$, meaning that there is no difference in terms of Persuasiveness. This result also contrasted with the previous one. Littrell, 2002 , p. 40 also found the same result that there is no differences in terms of Persuasiveness.

Table 4. Independent sample t-Test in Leadership Behaviour between European Expatriates

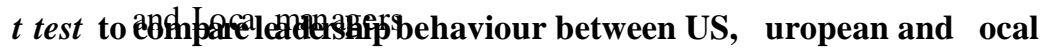

\begin{tabular}{|c|c|c|c|c|}
\hline \multirow{2}{*}{$\begin{array}{l}\text { Dimension of } \\
\text { Leadership } \\
\text { Behaviour }\end{array}$} & \multicolumn{4}{|c|}{ Mean Difference } \\
\hline & $\begin{array}{ll}\text { US } & \begin{array}{l}\text { Diff=EB- } \\
\text { LB }\end{array}\end{array}$ & Sig & $\begin{array}{l}\text { European } \\
\text { Diff=EB-LB }\end{array}$ & Sig \\
\hline $\begin{array}{l}\text { Initiation of } \\
\text { Structure }\end{array}$ & 0.5700 & 0.004 & 0.7929 & 0.000 \\
\hline Consideration & 0.6433 & 0.003 & 0.6227 & 0.001 \\
\hline $\begin{array}{l}\text { Tolerance of } \\
\text { Uncertainty }\end{array}$ & -0.0331 & 0.852 & 0.2177 & 0.194 \\
\hline Persuasiveness & 0.0300 & 0.882 & 0.2612 & 0.093 \\
\hline
\end{tabular}

\section{Hypothesis \#5}

By applying t-test (Table 4), it was proved that sig. 2-tailed $(0.004)<(0.01)$. As a result, the null hypothesis is rejected. Consequently, there is a significant difference in leadership behaviour for Initiating Structure between US expatriates and local mangers. The result is consistent to previous research conducted by Selmber (1997) with significant value of (0.0037). However, the recent finding is till the same in the category that there is difference in terms of Intiating Structure between expatriates and local managers. So that, it can be concluded that this recent results have had a consistent result from the past research until now.

\section{Hypothesis \#6}

As previously mentioned by Selmer (1997), they stated that there is a different in terms of Consideration with $p$ value of 0.0053 , the current study shows the consistency result of 0.003 , which means lower than 0.01. Therefore, the null hypothesis is rejected meaning that here is a difference in terms of Consideration.

\section{Hypothesis \#7}

Based on the test statistic, it can be summarized that there is no difference in 
leadership behaviour for Tolerance of Uncertainty between US expatriates and local managers, because the significant value is 0.852 , which is above 0.1 . this result has discrepancy with the prior research conducted by Selmer (1997), which stated that there is a difference in terms of Tolerance of Uncertainty, with $\mathrm{p}$ value $(0.0028)<(0.001)$.

\section{Hypothesis \#8}

The result shows the $\mathrm{p}$ value of $(0.882)>$ $(0.1)$, meaning that there is no difference in terms of Persuasiveness. This recent study contrasted to the the previous research

\section{Hypothesis \#9}

By applying t-test, it was proved that sig.2tailed $(0.000)<(0.001)$. As a result, the null hypothesis is rejected. Consequently, there is a significant difference in leadership behaviour for Initiating Structure between European expatriates and local managers. The result is contrast to previous research conducted by Selmer (1997) with significant value of (0.10). However, the recent finding is still the same in the category that there is difference in terms of Initiating Structure between expatriates and local managers. It can be concluded that this recent result is different from the pprevious one.

\section{Hypothesis \#10}

As presiously mentioned by Selmber (1997), they stated that there is a difference in terms of Consideration with $p$ value of 0.0025 , the current study shows the consistency result of 0.001 , which means higher than 0.01. Therefore, the null hypothesis is rejected meaning that there is a difference in terms of Consideration between European Expats and local managers.

\section{Hypothesis \#11}

Based on the test statistic, it can be summarized that there is no difference in leadership behaviour for Tolerance of
Uncertainty between European expatriates and local managers, because the significant value is 0.194 which is bigger than 0.1 .

\section{Hypothesis \#12}

The result whos the $\mathrm{p}$ value of $(0.093)<$ (0.1), meaning that there is a difference in terms of Persuasiveness. This recent study incoherent to the previous research conducted by Selmer (1997) stated that there is a difference in Persuasiveness with significant level of 0.014 .

\section{CONCLUSION}

Based on the analysis, the researcher came up with the conclusions that there is a difference between expats and local managers in their initiating structure and consideration.

The same result also reflected that there is a difference between US expat and local managers in terms of initiating structure and consideration.

Eventually, it is pointed out that there is a significant different in leadership behaviour between other European expatriates and local managers in terms of initiating structure, consideration, and persuasiveness.

The researcher compared the previous research conducted by Selmer (1997), which used twelve dimensions with this one only used four dimensions to measure the differences. Nevertheless, the results of those dimensions were quite similar to those in the prior research.

In overall, the conclusion is that there is a significant different in leadership behavior between expatriates and local managers. The findings also supported by Smith, Misumi, et al, 1989, p. 102 that specific behaviors would vary across cultures and there is differences in leader behaviors.

\section{IMPLICATION}

This comes to the implication for both practitioners and researchers of international management which can be 
depicted from these findings. Our results seem to imply that expatriates are perceived by their Indonesian subordinates as better than the local ones, meaning that pre departure cross cultural training would be less necessary. However that such cultural training is merely to make them acquire new skills that may lead to psychological barriers.

In addition, intensive management training programs for local managers is needed so that both categories of managers would be able to apply the most suitable leadership behavior to their Indonesia subordinates based on the local culture in general.

\section{REFERENCES}

Bass, B (1990). Bass \& Stogdill's Handbook of Leadership. Theory, Research \& Managerial Applications $\left(3^{\text {rd }} e d\right)$.. New York: the Free Press.

Black, J.S. \& Porter,L. W. (1991). Managerial behaviors and job performance: A successful manager in Los Angeles may succeed in Hong Kong. Journal of Internatonal Business Studies. 22(1), 99-113

Dessler, G. 2000. Human Resource Management. New Jersey: Prentice Hall.

Hughes, R.L., Ginnett, R.C. \& Curphy, G.J. 2002. Leadership: Enhancing the lessons of experience. $4^{\text {th }}$ ed. USA: Irwin.

Hussey, J. \& Hussey, R. 1997. Business Research: A Practical guide for undergraduate and postgraduate students. London: MacMillan Pres.
Jackson, T. 1995. Cross-Cultural Management. Oxford: ButterworthHeinemann

Littrell, R. M., 2002. Desirable leadership behaviours of multi-cultural managers in China. Journal of Management Development. 22(1), 574

Malhotra, M. K. \& Grover, V. (1998). An assessment of survey research in POM: from constructs to theory. Journal of Operations Management, 16(4), 407-425.

Mendenhall, N. and Oddou, G. (1985). The dimensions of expatriates' acculturation: a review. Academy of Management Review, 10, 39-47.

Selmer, J. 1997. Differences in leadership behaviour between expatriate and local bosses as perceived by their subordinates. Leadership \& Organizational Development Journal, 18_(1). 13-22.

Smith, P. B., Misumi, J., Tayeb, M., Peterson, M. and Bond, M. (1989). On the generality of leadership style measures across cultures. Journal of Occupational Psychology, 62, 97109.

Suutari. V., \& Brewster, C. (2001). Expatriate management practices and perceived relevance: Evidence from Finnish expariates. Personnel Review, 30 (5), 554-577.

Ticehurst. G. W. \& Anthony, J.V. 2000. Business research method: A managerial approach. French Forest, NSW: Pearson. 
MAJALAH SAINSTEKES 4 (2) : (2017) 